\title{
Knowledge Management Strategy, Innovation, and Performance in Small Business Enterprise in Indonesia
}

\author{
Aryo Bismo'; Wensin Halim²; Monica Andini Erwinta ${ }^{3 *}$ \\ ${ }^{1,2,3}$ Management Department, BINUS Business School Undergraduate Program, Bina Nusantara University \\ Jl. Kebon Jeruk Raya No. 27, Kebon Jeruk, Jakarta 11530, Indonesia \\ 1aryo.bismo001@binus.ac.id; ${ }^{2} w e n s i n . h a l i m @ b i n u s . a c . i d ;{ }^{3}$ monica.erwinta@binus.ac.id
}

Received: $05^{\text {th }}$ February 2021/ Revised: $18^{\text {th }}$ March 2021/ Accepted: $30^{\text {th }}$ March 2021

\begin{abstract}
How to Cite: Bismo, A., Halim, W., \& Erwinta, M. A. (2021). Knowledge management strategy, innovation, and performance in small business enterprise in Indonesia. The Winners, 22(1), 67-73.

https://doi.org/10.21512/tw.v22i1.7045
\end{abstract}

\begin{abstract}
The research aimed to provide view about the knowledge management strategies that specifically testing both codification and personalization, and their consequences on innovation and performance in small business enterprise. Data were collected from 46 small business enterprises in Indonesia through online questionnaires, and were analysed using structural equation modelling. The results reveal that knowledge management strategies codification and personalization-have impacts on innovation and performances directly and indirectly through the increase on innovation capability. It is considered that the research will help small business enterprises to establish a good knowledge management strategy to obtain better profit on a specific condition and environment.
\end{abstract}

Keywords: knowledge management strategy, innovation, performance, small business enterprise

\section{INTRODUCTION}

Development of technology in industry 4.0 makes competition become more rigid than before, and brings business into the next level of competition to survive. López-Nicolás and MeroñoCerdán (2011) and Shujahat et al. (2019) define knowledge management as the explicit and systematic management of vital knowledge-and its associated processes of creation, organization, diffusion, use and exploitation. It is essential for a business to build a competitive advantage by establishing a good strategy of knowledge management (López-Nicolás \& MeroñoCerdán, 2011). Therefore, it is considered that the firm on the small business enterprises (SBE) in Indonesia become the focus of the research since it is important for them to establish knowledge management and innovation to keep thriving in such competition.

Marzal (2019) shows that the stretching of the e-commerce industry has also developed a number of local unicorns - enterprise with value above US\$ 1 million such as Tokopedia and Bukalapak. Foreign players also enjoy the vantage of Indonesian e-commerce, such as Lazada and Shopee (Singapore), and JD.id (China). With great potential, the digital industry is one of the sectors that can be relied on to sustain economic growth and encourage equity as well considered as a good economic value to be utilized by SBE players to reach more market share and obtain more profit (Rahman, 2016).

Nevertheless, this also creates various agile competitions over technology and internals. Many regulations, innovations and tactics are made to accelerate and develop an electronic-based trading system to spur the growth of the national digital industry by developing technology, internet, and logistics as the expansion of internet services is a major prerequisite for the growth of an e-commerce business and facilitating connectivity (Rahayu, 2019). Therefore, SBE needs to form a strong and comprehensive data, information network and innovation.

In the area that becomes the center of change, a business must be able to meet and respond to various changes and levels of service to customers. Services must be provided as to meet customer expectations. Otherwise customers will not stay loyal (Ariyanti, 2017). At this point, decision making and response must be fast, so it is necessary to take advantage of enormous data and innovation to deliver the best performance to meet market needs and demands to achieve competitive advantage ("Genjot daya saing industry", 2018). For this purpose, user data is the key sources to grow a business. Knowledge management is 
able to provide further recommendation about unique services from a customer since today's businesses need to see guidance that a company must be able to respond to its customers in real time (Nawab et al., 2015).

Knowledge management strategy is related to a process and infrastructure that firms obtain, create, and share knowledge to formulate a strategy and decision making of the company (North \& Kumta, 2018). Knowledge management strategy can align company's goal with the resources and capabilities company obtain by establishing intellectual and strategic requirements as to reduce the gap between what the company knows and what actually happens (Nawab et al., 2015).

The typology of knowledge strategies can be distinguished between personalization and codification of knowledge. The classification is differentiated based on tacit knowledge and explicit knowledge, which differs on the use of information technology (Karamat et al., 2019). In codification strategy, determinations are extracted from the person who develops them, made independent of that person, and reused for various purposes within same condition. Meanwhile, strategies that are oriented towards tacit knowledge (human or personalization) are non-complementary with respect to organizational performance (Choi \& Lee, 2003).

Codification knowledge management captures existing knowledge, and then transfers and implement to similar situations whereas personalization knowledge management focuses on dialogue between individuals, new knowledge that is shared, synthesized, and created (Obeidat, Al-Suradi, \& Tarhini, 2016; Mohapatra et al., 2016; Dingsøyr, 2019). Both personalization and codification of knowledge promote innovation and enable competitive advantage (Raudeliūnienè, Davidavičienè, \& Jakubavičius, 2018).

Knowledge management is key in strategic management and innovation research (Girard \& Girard, 2015). The description of knowledge management varies, including creation, diffusion, feeding and application of either existing or new knowledge. Knowledge management intends to manage the intellectual and social capital of individuals to improve the learning abilities of an organization that allows the innovation process (Rahimi et al., 2017).

The knowledge management process is the process of acquiring knowledge, converting knowledge, sharing, and applying knowledge to improve company performance and help organization in achieving success as measured from a financial, market and internal perspective of a company (Abualoush et al., 2018; Raudeliūnienè, Davidavičienè, \& Jakubavičius, 2018). Innovation efforts include finding, discovering, experimenting, and developing new technologies, products or services with new production processes or even organizational structures. Innovation can also be defined as the process of implementing a new idea in something new (Borghini, 2005).

Damanpour and Evan (1984) illustrate that innovation has several characteristics, including new elements, new structures or administrative systems, new policies, new plans or programs, new production processes, and new products or services. Innovation is categorized as a new world where there are new products for companies, additional product lines, improvements or revisions to product lines, cost reduction, or product repositioning, in which new innovations are characterized as radical innovations while others are additional innovations (Darroch, 2005).

Innovation process is very dependent on knowledge, especially on tacit knowledge (Ganguly et al., 2019). The new knowledge is considered highly valuable and can be created and converted into a new product, service, or process that produces a competitive advantage for a company (Lee et al., 2016) The new development can take place by turning general knowledge into specialized knowledge (Meroño-Cerdán \& López-Nicolás, 2017). The strong interaction between knowledge management and innovation has been empirically tested by Jantunen (2005) and Khan et al. (2020).

Company performance is a multidimensional concept, in which the company's position against its competitors will be considered in assessing the company's performance (Meroño-Cerdán \& LópezNicolás, 2017). A comprehensive view of company performance does not only consider the financial perspective of the company but also the monitoring of the company's value creation (Meroño-Cerdán \& López-Nicolás, 2017). The company performance is often seen from three perspectives: 1) the company's financial performance which includes market performance such as profitability, growth, and customer satisfaction; 2) the process performance which refers to the quality and efficiency of the company; 3 ) the company's internal performance which refers to the individual capabilities of the company such as employee qualifications, employee satisfaction and creativity.

According to Darroch (2005), company performance usually uses internal comparative and reflective performance measures. For instance, the company's performance is compared with the average of other competitors in the industry, whether it is superior and profitable. Meanwhile, on the internal reflective, for instance, if the company achieves the highest profit this quarter for the last ten years, the performance measure includes financial and nonfinancial terms such as process performance and internal company.

Knowledge management is stated to expand the scope of creativity and enhance the innovation process through the movement and development of new knowledge (Nawab et al., 2015). Effective knowledge management, in addition, is a determining factor for the success of launching new products since knowledge contributes to producing creative thinking resulting in innovation (Borghini, 2005). Therefore, effective knowledge management is seen as the 
biggest contributor to the formation and smoothness of corporate innovation (Darroch, 2005). Pérez-Luño, Alegre, and Valle-Cabrera (2019) state that most of the exploration and innovation come from knowledge focused on tacit knowledge, while López-Cabarcos et al. (2019) suggest a positive impact that the reuse of explicit knowledge (codification strategy) would come up with great development of radical innovation (Möller \& Halinen. 2017; Barão et al., 2018).

Jantunen (2005) reveals that knowledge acquisition, dissemination, and utilization of knowledge will form new knowledge creation capabilities that enhance corporate innovation. LópezCabarcos et al. (2019) investigate the relationship between tacit knowledge and innovation ability, which shows that increasing the innovation capability of a company is highly dependent on the degree of utilization of the organization's tacit knowledge and is influenced by internal factors of the company. Abdi et al. (2018) explain that consistency and persistence in knowledge management is the best way that companies can do to increase technological innovation, products and/or services through knowledge acquisition and application. Hence the research aims to prove the theory that knowledge management is one of the factors to ensure the success of developing innovation.

Knowledge management can improve company performance and competitiveness (Dalkir, 2017; Mardani et al., 2018). The performance of the knowledge management system must combine financial and non-financial measures within the firm since different performance dimensions will be influenced by different knowledge management strategies (Wu \& Lin, 2004). The influence of each knowledge management (codification and personalization) on different performance dimensions may result in different impacts (Wu \& Lin, 2004). The personalization strategy may be more valuable in increasing the competitiveness of the company than the codification strategy, but an explicitly oriented coding strategy is more profitable for enhancing the performance of the company (Martinez-Conesa, SotoAcosta, \& Carayannis, 2017). Meanwhile, codification knowledge management saves time and increases coordination efforts while personalization strategies improve quality, competence, and innovation ability (Wu \& Lin, 2004). Based on these views, the research aims to find out whether the knowledge management is one of the factors that improves performance directly or indirectly with enhancing innovation.

The research proposes the similar research model, as seen in Figure 1, that has already been tested by López-Nicolás and Meroño-Cerdán (2011). The research is different from previous research by two aspects: 1) the conceptual model will be more detailed as the firm performance is divided into three performances - financial, process and internal performance; 2) it lays on the context of the research, which is the situation that encourage SBE to learn about knowledge management strategy and innovation to improve the firm performance.

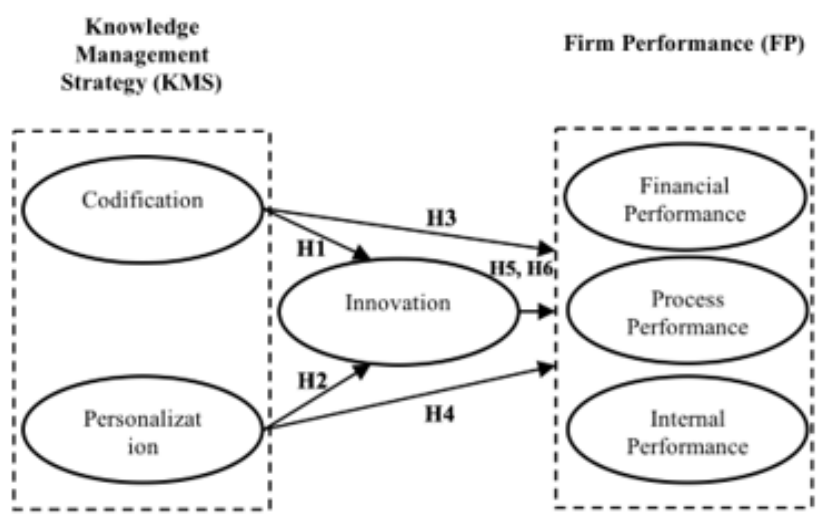

Figure 1 Conceptual Model

Source: Adapted from López-Nicolás \& Meroño-Cerdán (2011)

Moreover, the research is important due to the current situation of COVID-19 pandemic in Indonesia. The facts have shown that the impacts of the COVID-19 pandemic on SMEs in Indonesia bring businesses on this level of competition into a slump. Data from the cooperative ministry illustrates that 1.785 cooperatives and 163.713 micro, small and medium enterprises (MSMEs) are affected by the pandemic (Amri, 2020). According to Mudassir (2020), at least $39,9 \%$ of small and medium enterprises (SME) have decided to reduce the stock of goods during the largescale social restrictions (PSBB). Meanwhile, $16,1 \%$ of SMEs have decided to deduct employees due to the closure of physical stores. The condition will become another reason for SBE actors, especially in Indonesia, to realize the importance of managing the knowledge and bringing up the innovation to come up with better performance.

The research aims to extend more perspectives regarding the previous research by Darroch (2005), discussing about relationship of knowledge management, innovation and performances. The research is the continuation from López-Nicolás and Meroño-Cerdán (2011) that have specifically tested both codification and personalization and the consequences on innovation and on financial and nonfinancial performances.

The research brings a different point of view from previous research since it focuses on SBE in Indonesia and is developed during COVID-19 pandemic in 2020. It is expected that the research conclusion will help SBEs to build a good knowledge management strategy, and to achieve better profit on a specific condition and environment. To test the assessment, hypothesis are proposed:

H1 : Codification knowledge management strategy enhances innovation.

$\mathrm{H} 2$ : Personalization knowledge management strategy enhances innovation.

H3 : Codification knowledge management strategy has direct effect on firm performance. 
H4 : Personalization knowledge management strategy has direct effect on firm performance.

H5 : Codification knowledge management strategy has an indirect effect on firm performance through an increase on innovation capacity.

H6 : Personalization knowledge management strategy has an indirect effect on firm performance through an increase on innovation capacity.

\section{METHODS}

The research implements quantitative methods. The conceptual model shown in literature review is empirically tested through survey among Indonesian SMEs. The sampling procedure is based on probability sampling technique with stratified sampling methods, in which the data are collected through online questionaries. The respondents are selected based on the ownership of business and the sum of employee that they have. The selected respondents are required to represent the SBE characteristics which only have maximum 30 employees on their firm. The research assumes $10 \%$ error and $90 \%$ confidence level. After conducting survey to $46 \mathrm{SBE}$ owner in Indonesia, 44 SBEs owners' valid responses are obtained from different categories of industries. Complete description are shown in Table 1.

Table 1 Respondent Profile

\begin{tabular}{clr}
\hline No. & \multicolumn{1}{c}{ Measurement } & Sample (\%) \\
\hline & Company size: & \\
1 & $\leq 30$ employees & 95,7 \\
2 & $>30$ employees & 4,3 \\
& SME Owner Age: & \\
3 & $\leq 30$ years old & 76 \\
4 & $>30$ years old & 24 \\
& Sector: & \\
5 & Food \& Beverages & 40 \\
6 & Education & 2 \\
7 & Health & 4 \\
8 & Transportation & 4 \\
9 & Retail & 13 \\
10 & Online & 30 \\
11 & Others & 7 \\
& Geographical distribusition: & \\
12 & Jakarta area & 68 \\
13 & Outside Jakarta area & 13 \\
14 & Online & 19 \\
\hline
\end{tabular}

Source: Data processing (2020)

Variables used on the research are measured with multi-item scales that have been tested by LópezNicolás \& Meroño-Cerdán (2011). The items used on the research are also based on similar types of research, which are knowledge management (KM), innovation (INN) and, performance (FP) measures (Choi \& Lee, 2003).

Confirmatory factor analysis (CFA) conducted for reliability and validity, the Cronbach's Alpha and composite reliability above 0,70 chosen based on (Hair, 2001), the average variance extracted (AVE) is above 0,50 according to Fornell \& Larcker (1981). The goodness-fit of model is observed based on nonsignificant Chi-square, Goodness Fit Index (GFI), Comparative Fit Index (CFI) and Incremental Fit Index (IFI) above 0,90, Root Mean Square Error of Approximation (RMSEA) below 0,80 and Root Mean Square Residual (RMR) between 0,05 and 0,06. The model structures are assessed using AMOS 20 and structural equation modelling (SEM) since all paths could be evaluated at once.

\section{RESULTS AND DISCUSSIONS}

The results of confirmatory factor analysis are to check the reliability and validity of the structures used for survey with questionnaires. Reliability and validity are checked using scale composite reliability (SCR) and average variance extracted (AVE) for construct validity, as seen on Table 2 . All constructs are suitable for analysis with the minimum score for composite reliability is 0,70 and for AVE is 0,50 . The results of CFA show that all constructs have already passed the minimum score.

Interesting results appear on research model testing. López-Nicolás and Meroño-Cerdán (2011) have shown that all hypothesis from $\mathrm{H} 1$ to $\mathrm{H} 4$ are supported on this model. However, as seen on Table 3, the results show different outcomes. Only $\mathrm{H} 1$ and $\mathrm{H} 4$ support innovation and firm performance directly. On the other hand, knowledge management strategies have secondary effect on firm's overall performancethrough an increase on organization innovation capability-which supports H5 and H6.

The findings prove that knowledge management is the essential factor for companies to innovate more, which differs from what Barley, Treem, and Kuhn (2018) have mentioned that personalization motivates employee to build some innovation. It can be concluded that SBEs in Indonesia believe that the advancement of technology become one of the important things for improving the innovation and enhance performance through innovation, especially in the COVID-19 pandemic, where online business is growing at a fast rate in Indonesia. The situation shows huge opportunities for growth and thus, innovation is needed where it is established from the personalization since the employees are motivated. Another interesting result shows that personalization directly affects firm performance. It comes out that the social interaction and employees' characteristics directly impact firm performance. The results are considered reasonable since the research is conducted in Indonesia where 
Table 2 Validity and Reliability

\begin{tabular}{clccccc}
\hline No & \multicolumn{1}{c}{ Mean } & & Item & Cronbach's Alpha & SCR & AVE \\
\hline 1 & Codification & 3,82 & 4 & 0,734 & 0,962 & 0,710 \\
2 & Personalization & 3,79 & 4 & 0,704 & 0,856 & 0,761 \\
3 & Innovation & 3,64 & 2 & 0,495 & 0,934 & 3,739 \\
4 & Financial performance & 3,72 & 3 & 0,327 & 0,713 & 0,374 \\
5 & Process performance & 3,93 & 4 & 0,731 & 0,862 & 0,626 \\
6 & Internal performance & 3,86 & 3 & 0,807 & 0,880 & 0,858 \\
\hline \multicolumn{6}{c}{$x^{2}: 2,165$, GFI: 0,59, CFI: 0,54, RMSEA: 0,165, IFI: 0,568, RMR: 0,090} \\
\hline
\end{tabular}

Table 3 Hypothesis Testing Result

\begin{tabular}{cllccc}
\hline No & & p - Value & Loadings & Results \\
\hline 1 & H1 & Cod $\rightarrow$ Inn & $0,072^{*}$ & 0,916 & Supported \\
2 & H2 & Pers $\rightarrow$ Inn & 0,890 & 0,080 & Not-supported \\
3 & H3 & Cod $\rightarrow$ FP & 0,198 & 0,201 & Not-supported \\
4 & H4 & Pers $\rightarrow$ FP & $0,091^{*}$ & 0,698 & Supported \\
5 & H5 & Cod $\rightarrow$ Inn $\rightarrow$ FP & $0,085^{*}$ & 0,214 & Supported \\
6 & H6 & Pers $\rightarrow$ Inn $\rightarrow$ FP & \\
\hline \multicolumn{5}{c}{ - Notes: $* \mathrm{p}<10 \%$} \\
\hline
\end{tabular}

the communication between employee and customers is believed more important rather than focusing on innovation internally.

The subordinate effect of knowledge management strategy on firm performance through the acceleration of firm innovation capacity (H5 and H6) is also substantiate. The result is consistent with several previous research by Santoro et al. (2018) and López-Nicolás \& Meroño-Cerdán (2011), mentioning that knowledge management strategies give significant impact and enhancement to the increasing of innovation capacity. It is proven that both knowledge management strategy and innovation will improve the overall firm performance-financial, process, and internal - which is a critical issue for the SBE during the pandemic as it changes people's behaviour and turns down the economic. Therefore, to compete and survive, it is essential for SBEs increase their performance through innovation and knowledge management.

\section{CONCLUSIONS}

The research has presented the approach to strategic knowledge management that refines innovation and firm's performance. In addition, it is shown that the risk of knowledge management strategies (codification and personalization) gives impacts on innovation and organization performance, which will become empirical evidence for future research. Apart from the risk, only personalization shows a great impact on the overall firm performance. This leads to the conclusions that the research could be relevant in many ways in helping SBEs to develop financial, process, and internal performances in the pandemic. It is suggested that changing business model into an online business seems crucial to survive the market shrinks.

The research result can be implemented to enterprises due to the new insight and useful findings for SBEs since firms currently tend to ignore the main function of knowledge management. Managers are suggested to implement knowledge management and adjust it to their firms, so they could elaborate strategy to increase performance through innovation. After understanding the primary use of knowledge management, enterprises can acknowledge the improvement especially on innovations, financial results, processes, and the capabilities of humanresource as a result of understandable knowledge management strategy (codification and personalization). Therefore, knowledge management strategy indirectly boosts the innovation and firm performance.

The research has some limitations. The first one lies on the sample which is obtained from Indonesia. Thus, findings and insight might be applied to ASEAN since the countries experience development on economics and technology the same way. Nevertheless, if the case is based on other continents, research may come up with different results Thus it is suggested future research use an international perspective, for example, combining firms from more than one country. However, reviewing companies from other countries across continents will have more challenges such as time difference, different company lifestyle, and different implementation of knowledge management. The second limitation lies on the questionnaires with subjective measures.

Future research is expected to consider objective 
measures for firm performance, for example Return on Investment (ROI) or Return on Assets (ROA). It is possible that researchers expand the examination on knowledge management strategy by studying more about learning outcomes.

\section{REFERENCES}

Abualoush, S., Masa'deh, R., Bataineh, K., \& Alrowwad, A. (2018). The role of knowledge management process and intellectual capital as intermediary variables between knowledge management infrastructure and organization performance. Interdisciplinary Journal of Information, Knowledge, and Management, 13, 279-309. https://doi.org/10.28945/4088.

Abdi, K., Mardani, A., Senin, A. A., Tupenaite, L., Naimaviciene, J., Kanapeckiene, L., \& Kutut, V. (2018). The effect of knowledge management, organizational culture and organizational learning on innovation in automotive industry. Journal of Business Economics and Management, 19(1), 1-19. https://doi.org/10.3846/jbem.2018.1477.

Amri, A. (2020). Dampak COVID-19 terhadap UMKM di Indonesia. BRAND Jurnal Ilmiah Manajemen Pemasaran, 2(1), 123-130. https://ejournals.umma. ac.id/index.php/brand/article/view/605/441.

Ariyanti, F. (2017, September 22). Perusahaan harus ubah strategi demi bertahan di era digital. Liputan6. https://www.liputan6.com/bisnis/read/3103505/ perusahaan-harus-ubah-strategi-demi-bertahan-diera-digital.

Barley, W. C., Treem, J. W., \& Kuhn, T. (2018). Valuing multiple trajectories of knowledge: A critical review and agenda for knowledge management research. Academy of Management Annals, 12(1), 278-317. https://doi.org/10.5465/annals.2016.0041.

Barão, A., de Vasconcelos, J. B., Rocha, Á., \& Pereira, R. (2017). A knowledge management approach to capture organizational learning networks. International Journal of Information Management, 37(6), 735-740. https://doi.org/10.1016/j. ijinfomgt.2017.07.013.

Borghini, S. (2005). Organizational creativity: Breaking equilibrium and order to innovate. Journal of Knowledge Management, 9(4), 19-33. https://doi. org/10.1108/13673270510610305.

Choi, B. \& Lee, H. (2003). An empirical investigation of knowledge management styles and their effect on corporate performance. Information \& Management, 40(5), 403-417. https://doi.org/10.1016/S03787206(02)00060-5.

Dalkir, K. (2017). Knowledge Management in Theory and Practice ( ${ }^{\text {rd }}$ Ed.). MIT Press.

Damanpour, F. \& Evan, W. M. (1984). Organizational innovation and performance: The problem of organizational lag. Administrative Science Quarterly, 29(3), 392-409. https://doi.org/10.2307/2393031.

Darroch, J. (2005). Knowledge management, innovation and firm performance. Journal of Knowledge Management, 9(3), 101-115. https://doi. org/10.1108/13673270510602809.

Dingsøyr, T. (2019). Knowledge management in mediumsized software consulting companies: An investigation of intranet-based knowledge management tools for knowledge cartography and knowledge repositories for learning software organisations. (Doctoral dissertation, Norwegian University of Science and Technology, Trondheim, Norway). https://ntnuopen. ntnu.no/ntnu-xmlui/handle/11250/249737.

Fornell, C. \& Larcker, D. F. (1981). Evaluating structural equation models with unobservable variables and measurement error. Journal of Marketing Research, 18(1), 39-50. https://doi.org/10.2307/3151312.

Ganguly, A., Talukdar, A., \& Chatterjee, D. (2019). Evaluating the role of social capital, tacit knowledge sharing, knowledge quality and reciprocity in determining innovation capability of an organization. Journal of Knowledge Management, 23(6), 11051135. https://doi.org/10.1108/JKM-03-2018-0190.

Genjot daya saing industri nasional, RI percepat bangun infrastruktur digital. (2018, July 25). Kementrian Perindustrian Republik Indonesia. https:// kemenperin.go.id/artikel/19468/ghs.

Girard, J. \& Girard, J. (2015). Defining knowledge management:Toward an applied compendium. Online Journal of Applied Knowledge Management, 3(1), 1-20. https://www.iiakm.org/ojakm/articles/2015/ volume3_1/OJAKM_Volume3_1pp1-20.pdf.

Hair, J, Anderson, R., Tatham, R., \& Black, W. (2001). Análisis Multivariante ( $5^{\text {th }}$ Ed.). Madrid: Prentice Hall.

Jantunen, A. (2005). Knowledge-processing capabilities and innovativeperformance: an empirical study.European Journal of Innovation Management, 8(3), 336-349. https://doi.org/10.1108/14601060510610199.

Khan, K. U., Atlas, F., Ghani, U., Akhtar, S., \& Khan, F. (2020). Impact of intangible resources (dominant logic) on SMEs innovation performance, the mediating role of dynamic managerial capabilities: Evidence from China. European Journal of Innovation Management. https://doi.org/10.1108/ EJIM-07-2020-0276.

Karamat, J., Shurong, T., Ahmad, N., Afridi, S., Khan, S., \& Khan, N. (2019). Developing sustainable healthcare systems in developing countries: Examining the role of barriers, enablers and drivers on knowledge management adoption. Sustainability, 11(4), 954. https://doi.org/10.3390/su11040954.

Lee, V. H., Foo, A. T. L., Leong, L. Y., \& Ooi, K. B. (2016). Can competitive advantage be achieved through knowledge management? A case study on SMEs. Expert Systems with Applications, 65, 136-151. https://doi.org/10.1016/j.eswa.2016.08.042.

López-Cabarcos, M. Á., Srinivasan, S., Göttling-OliveiraMonteiro, S., \& Vázquez-Rodríguez, P. (2019). Tacit knowledge and firm performance relationship. The role of product innovation and the firm level capabilities. Journal of Business Economics and Management, 20(2), 330-350. https://doi. org/10.3846/jbem.2019.9590.

López-Nicolás, C. \& Meroño-Cerdán, Á. L. (2011). 
Strategic knowledge management, innovation and performance. International Journal of Information Management, 31(6), 502-509. https://doi. org/10.1016/j.ijinfomgt.2011.02.003.

Mardani, A., Nikoosokhan, S., Moradi, M., \& Doustar, M. (2018). The relationship between knowledge management and innovation performance. The Journal of High Technology Management Research, 29(1), 12-26. https://doi.org/10.1016/j. hitech.2018.04.002.

Martinez-Conesa, I., Soto-Acosta, P., \& Carayannis, E. G. (2017). On the path towards open innovation: Assessing the role of knowledge management capability and environmental dynamism in SMEs. Journal of Knowledge Management, 21(3), 553-570. https://doi.org/10.1108/JKM-09-2016-0403.

Marzal, J. (2019, August 19). Revolusi industri 4.0, bagaimana meresponnya. Universitas Jambi. https:// www.unja.ac.id/2019/08/19/revolusi-industri-4-0bagaimana-meresponnya/.

Meroño-Cerdán, A. L., \& López-Nicolás, C. (2017). Innovation objectives as determinants of organizational innovations. Innovation, 19(2), 208226. https://doi.org/10.1080/14479338.2016.12764 07.

Mohapatra, S., Agrawal, A., \& Satpathy, A. (2016). Designing Knowledge Management-Enabled Business Strategies. Cham: Springer.

Möller, K., \& Halinen, A. (2017). Managing business and innovation networks-From strategic nets to business fields and ecosystems. Industrial Marketing Management, 67, 5-22. https://doi.org/10.1016/j. indmarman.2017.09.018.

Mudassir, R. (2020, July 22). Dampak COVID-19 ke UKM, 16 persen pelaku usaha pangkas karyawan. Bisnis.com. https://ekonomi.bisnis.com/ $\mathrm{read} / 20200722 / 9 / 1269901 /$ dampak-covid-19-keukm-16-persen-pelaku-usaha-pangkas-karyawan.

Nawab, S., Nazir, T., Zahid, M. M., \& Fawad, M. S. (2015). Knowledge management, innovation and organizational performance. International Journal of Knowledge Engeneering, 1(1), 43-48. https://doi. org/10.7763/IJKE.2015.V1.7.

North, K. \& Kumta, G. (2018). Knowledge Management: Value Creation through Organizational Learning. New Delhi: Springer.

Pérez-Luño, A., Alegre, J., \& Valle-Cabrera, R. (2019). The role of tacit knowledge in connecting knowledge exchange and combination with innovation. Technology Analysis \& Strategic Management, 31(2), 186-198. https://doi.org/10.1080/09537325.2 018.1492712.

Obeidat, B. Y., Al-Suradi, M. M., \& Tarhini, A. (2016). The impact of knowledge management on innovation: An empirical study on Jordanian consultancy firms. Management Research Review, 39(10), 1214-1238. https://doi.org/10.1108/MRR-09-2015-0214.

Rahayu, N. (2019, February 19). Pertumbuhan e-commerce pesat di Indonesia. Warta Ekonomi. https://www. wartaekonomi.co.id/read216302/pertumbuhan-ecommerce-pesat-di-indonesia.

Rahimi, E., Rostami, N. A., Shad, F. S., \& Vafaei, V. (2017). The importance of knowledge management on innovation. Applied Mathematics in Engineering, Management and Technology, 5(1), 68-73. https:// www.researchgate.net/publication/328791839 The_importance_of_knowledge_management_on innovation.

Rahman, A. F. (2016, October 13). E-commerce Indonesia: Siapa yang bertahan dan terbuang? detikInet. https:// inet.detik.com/cyberlife/d-3319511/e-commerceindonesia-siapa-yang-bertahan-dan-terbuang.

Raudeliūnienè, J., Davidavičienè, V., \& Jakubavičius, A. (2018). Knowledge management process model. Entrepreneurship and Sustainability Issues, 5(3), 542-554. https://doi.org/10.9770/jesi.2018.5.3(10).

Santoro, G., Vrontis, D., Thrassou, A., \& Dezi, L. (2018). The Internet of Things: Building a knowledge management system for open innovation and knowledge management capacity. Technological Forecasting and Social Change, 136, 347-354. https://doi.org/10.1016/j.techfore.2017.02.034.

Shujahat, M., Sousa, M. J., Hussain, S., Nawaz, F., Wang, M., \& Umer, M. (2019). Translating the impact of knowledge management processes into knowledgebased innovation: The neglected and mediating role of knowledge-worker productivity. Journal of Business Research, 94, 442-450. https://doi. org/10.1016/j.jbusres.2017.11.001.

Wu, I. \& Lin, H. (2004). A strategy-based process for implementing knowledge management: An integrative view and empirical study. Journal of the American Society for Information Science and Technology, 60(4), 789-802. https://doi.org/10.1002/ asi.20999. 